\title{
Sustained virological response to treatment of chronic hepatitis C with peginterferon alfa and ribavirin
}

\author{
Junior André da Rosa ${ }^{1}$, Carine Raquel Blatt ${ }^{1,2}$, Kaite Cristiane Peres ${ }^{1}$, Bernd Heinrich Storb ${ }^{1}$, \\ Rochele Silva ${ }^{3}$, Mareni Rocha Farias ${ }^{1, *}$
}

${ }^{1}$ Federal University of Santa Catarina, UFSC, ${ }^{2}$ University of Southern Santa Catarina, UNISUL, ${ }^{3}$ Nereu Ramos Hospital, Florianópolis, SC

\begin{abstract}
This study aimed to evaluate the rate of sustained virological response (SVR) and the clinical and treatment characteristics of patients with chronic hepatitis $\mathrm{C}(\mathrm{CHC})$. A retrospective uncontrolled cohort study was conducted among patients who received treatment for CHC between 2005 and 2008 attended at the Center for the Application and Monitoring of Injectable Medications, in Florianopolis, SC, Brazil. The inclusion criteria were: patients over 18 years of age, with a confirmed diagnosis of chronic hepatitis $\mathrm{C}$ according to Brazilian guidelines, treated with PEG-IFN alfa-2a or $2 \mathrm{~b}$ associated with RBV. A total of 188 patients were included in the study: $70 \%$ men, 59\% genotype 1, 27\% coinfected with HIV, 31\% with cirrhosis. The SVR rate, calculated by probability theory, was determined as $26 \%$ ( $\max =57.4 \%$ and $\min =12.8 \%$ ) and the intention to treat was $12.8 \%$. Associations between Sustained Virological Response (SVR) and the variables sex $(p=0.017)$, age $(p=0.003)$, genotype $(p=0.648)$ and cirrhosis $(p=0.275)$, were determined in the bivariate analysis and only sex and age were significantly associated with SVR. The SVR rate was considered low, which can be partially explained by patients' unfavorable pretreatment characteristics.
\end{abstract}

Uniterms: Hepatitis C. Hepatitis C Chronic. Effectiveness. Interferon alfa-2a. Interferon alfa-2b.

O objetivo do estudo foi avaliar a taxa de resposta viral sustentada (RVS) e as características clínicas e do tratamento dos pacientes portadores de hepatite $\mathrm{C}$ crônica. Realizou-se uma coorte retrospectiva não controlada com recorte temporal dos anos de 2005 a 2008, dos pacientes atendidos no Polo de Aplicação e Monitoramento de Medicamentos Injetáveis, em Florianópolis, SC. Os critérios de inclusão foram: pacientes maiores de 18 anos, com diagnóstico confirmado de hepatite $\mathrm{C}$ crônica de acordo com o protocolo brasileiro, tratados com PEG-IFN alfa-2a ou $2 \mathrm{~b}$ associado a ribavirina. Total de 188 pacientes foi incluído no estudo, $70 \%$ homens, $59 \%$ genótipo $1,27 \%$ co-infectados com o HIV e $31 \%$ apresentando cirrose. A taxa de RVS calculada através da teoria das probabilidades foi de $26 \%$ (max=57,4\% and $\min =12,8 \%$ ) e por intenção de tratamento de $12,8 \%$. Verificou-se a associação da RVS com as variáveis: sexo $(p=0,017)$, idade $(p=0,003)$, genótipo $(p=0,648)$ e presença de cirrose $(p=0,275)$. Somente sexo e idade foram associados significativamente com a RVS. A taxa de RVS foi considerada baixa e, em parte, pode ser explicada pelas características desfavoráveis dos pacientes para a obtenção de RVS.

Unitermos: Hepatite C. Hepatite C Crônica. Efetividade. Interferona alfa-2a. Interferona alfa-2b.

\section{INTRODUCTION}

Estimates indicate that $3 \%$ of the world population is infected by hepatitis $\mathrm{C}$ virus (HCV) and that a significant number of people are unaware of their condition as carriers

\footnotetext{
*Correspondence: M. R. Farias. Departamento de Ciências Farmacêuticas, Farmácia Escola, Centro de Ciências da Saúde, Universidade Federal de Santa Catarina, Campus Universitário Trindade, 88040-900 - Florianópolis - SC, Brasil. E-mail: marenif@yahoo.com.br
}

of HCV (Alter, 1995; Shepard, Finelli, 2005). Treatment of hepatitis $\mathrm{C}$ is based on the association of interferon alfa (INF) and ribavirin (RBV) or peginterferon alfa (PEGIFN) and RBV (Brazil, 2007; National Institute for Health and Clinical Excellence, 2006; NIH, 2002). Treatment aims to halt the progression of liver disease by inhibiting viral replication. Reduction in hepatic inflammatory activity tends to prevent progression to cirrhosis and hepatocellular carcinoma (National Institute for Health and 
Clinical Excellence, 2006; NIH, 2002). The incidence of adverse effects during treatment reduces patient quality of life, while sustained virological response (SVR) to treatment seems to improve patient quality of life (Blatt et al., 2009). A systematic review comparing the quality of life in patients who presented SVR and those who did not indicated that quality of life is worse in patients who do not achieve SVR (Spiegel et al., 2005).

In the early 1990 s, IFN applied three times a week was the only therapeutic option for treatment of hepatitis $\mathrm{C}$ and SVR rates were low, ranging between 5 and $20 \%$ (Poynard et al., 1996). Currently, therapeutic success is achieved in about 40 to $80 \%$ of patients using a combination of IFN and RBV or PEG-IFN and RBV, depending on host and viral factors (Fried et al., 2002; Hadziyannis et al., 2004; Shepherd et al., 2007; Manns et al., 2001).

Despite the findings of clinical trials, the results of effectiveness in Brazil remain below expectations. In a study conducted in Rio Grande do Sul involving patients with genotype 1 treated with PEG-IFN and RBV, the SVR rate was $35.3 \%$ (Almeida et al., 2009). In another study conducted in Rio de Janeiro, the SVR rate with the use of PEG-IFN and RBV in naive patients was $53.0 \%$, including all genotypes (Brandão et al., 2006). In studies conducted in São Paulo, the SVR rate with the use of PEG-IFN and RBV in naive patients with genotype 1 varies from $42.5 \%$ to $51.7 \%$ (Narciso-Schiavon et al., 2010; Silva et al., 2007).

One of the main factors associated with low therapeutic effectiveness of hepatitis $C$ treatment is the high incidence of adverse effects that reduce the quality of life of patients, which often leads to discontinuation (Fried, Hadziyannis, 2004). The most common adverse events reported for PEG-IFN and RBV are muscular pain, fatigue, anemia, leukopenia, thrombocytopenia and depression (Fried, Hadziyannis, 2004; Mulhall, Younossi, 2008; National Institute for Health and Clinical Excellence, 2006; NIH, 2002).

Monitoring the response to treatment is achieved through molecular biology techniques (qualitative and quantitative HCV-RNA) at week four of treatment (rapid virological response, RVR), at week 12 of treatment (early virological response, EVR), at the end of treatment (end of treatment response, ETVR) and 24 weeks after completing treatment (SVR). The expected outcome of treatment, currently considered as cure, is the achievement of SVR, which is considered the maintenance of negative HCV RNA by qualitative PCR six months after the end of treatment (Fried, Hadziyannis, 2004; Mulhall, Younossi, 2008; National Institute for Health and Clinical Excellence, 2006; NIH, 2002).
Several factors can influence the results of hepatitis $\mathrm{C}$ treatment and may be associated with the therapy (treatment, dose and duration), the virus (genotype, viral load before treatment, resistant strains of $\mathrm{HCV}$, cirrhosis) and the patient (sex, age, Human immunodeficiency virus (HIV), Hepatitis B virus (HBV), obesity, compliance) (Fried, Hadziyannis, 2004; Mulhall, Younossi, 2008; National Institute for Health and Clinical Excellence, 2006; NIH, 2002).

In Brazil, the medications IFN, PEG-IFN and RBV are provided by the National Health Service (Sistema Unico de Saúde, SUS) through the Specialized Pharmaceutical Service Component (Componente Especializado da Assistência Farmacêutica, CEAF). The request for treatment is individual, according to clinical protocol. Moreover, according to this protocol, patients undergoing treatment with PEG-IFN must have their weekly doses applied in assisted treatment clinics or services specifically identified for these purposes by State and/or Municipal Health Secretaries (Brasil, 2007).

Although access to treatment for hepatitis $\mathrm{C}$ is guaranteed by the CEAF, currently, a significant number of patients still resort to the judicial system to ensure that the State provides their medications (Chieffi, Barata, 2009; Vieira, 2008).

The objectives of this work were to study the profile of patients who received medications for chronic hepatitis $\mathrm{C}$ treatment from the National Health Service and verify the rate of SVR to treatment with PEG-IFN associated with RBV.

\section{METHODOLOGY}

This is a retrospective uncontrolled cohort study conducted on patients who received treatment with PEG-IFN in association with RBV from January 2005 to December 2008 at the Polo de Aplicação e Monitoramento de Medicamentos Injetáveis do Hospital Nereu Ramos (PAMMI/HNR), Florianópolis, SC, Brazil.

The inclusion criteria were: patients over 18 years of age, with a confirmed diagnosis of chronic hepatitis $\mathrm{C}$ according Brazilian guidelines, treated with PEG-IFN alfa- $2 a$ or $2 b$ associated with RBV, who were administered the medication at the PAMMI/HNR. The exclusion criteria were: patients aged less than 18 years old, those who refused to join the study, monotherapy and acute hepatitis C.

Data were collected from patient records and the variables considered were: patient characteristics, clinical and laboratory data and data related to treatment. These categories are described separately in the results.

The variables analyzed were: sex, age, degree of 
fibrosis, viral genotype, presence of HIV coinfection, presence of coinfection with HBV, type of PEG-IFN used, prescription origin (public or private), form of access to medications (administrative or lawsuit), retreatment, type of first treatment, treatment conclusion, ETVR and SRV, grouped as variables related to treatment.

The laboratory exam data were obtained from exam reports or patient records.

Patients were classified according to liver biopsies, into two groups: non-cirrhotic and cirrhotic. The presence of cirrhosis was based on a score of fibrosis grade 4 (F4) according to the Metavir group scoring system and conclusive reports of cirrhosis according to the classification of the Brazilian Society of Pathology.

For patients with a virus genotype other than 1, the ETVR was considered to be negative PCR results obtained 24 weeks after the onset of treatment and for genotype 1, after 48 weeks. SVR was considered the maintenance of negative HCV RNA by qualitative PCR 24 weeks after the end of treatment. SVR was calculated using the theory of probabilities and by intention to treat.

Data were double entered into a database built on Epi date 3.1 and later analyzed using Epi Info software, version 3.5.1.

The variables were analyzed by descriptive statistics and associations between predictor variables and SVR were determined by the Chi square test, with $P<0.05$ considered statistically significant.

The study was approved by the Ethics Committee on Human Research of the Federal University of Santa Catarina, protocol no. 304/2006.

\section{RESULTS}

A total of 211 patients received treatment during the period studied. Thirty-one patients were excluded from the study because they had acute hepatitis C or they used PEG-IFN monotherapy or they began their treatment at home. The sample included 188 patients.

Regarding patient characteristics, $70 \%$ were male, $80 \%$ aged over 40 years-old and $96 \%$ were white, while among the risk factors for hepatitis $\mathrm{C}$, the principal factors identified were blood transfusion (26\%) and injectable drug use (22\%) (Table I).

The clinical and laboratory characteristics evaluated in the study are presented in Table II. Data from 128 biopsies were retrieved (62 results were determined using the Metavir Classification and 66 by the classification of the Brazilian Society of Pathology), with $31 \%$ of the samples presenting conclusive reports of cirrhosis. In addition, $59 \%$ of patients presented genotype $1,27 \%$ were
TABLE I - Characterization according to sex, age, race and $\mathrm{HCV}$ exposure route of patients receiving treatment for chronic hepatitis $\mathrm{C}$ at the PAMMI/HNR between 2005 and 2008

\begin{tabular}{lc}
\hline Variable & $\%(\mathrm{~N}=188)$ \\
\hline Sex & \\
$\quad$ Male & 70 \\
Age & \\
$\quad \geq 40$ years old & 80 \\
Race & \\
$\quad$ White & 96 \\
Risk factor & \\
$\quad$ Blood transfusion & 26 \\
$\quad$ Injectable drug use & 22 \\
$\quad$ Sexual relations & 5 \\
$\quad$ Reusable syringes and/or needles & 4 \\
$\quad$ Surgical procedure & 3 \\
$\quad$ Occupational exposure & 3 \\
$\quad$ Unknown route & 20 \\
$\quad$ Information not available & 17 \\
\hline
\end{tabular}

TABLE II - Clinical parameters prior to treatment of patients receiving treatment for chronic hepatitis $\mathrm{C}$ at the PAMMI/HNR between 2005 and 2008

\begin{tabular}{lc}
\hline Variable & $\%(\mathrm{~N}=188)$ \\
\hline Liver histology & \\
Cirrhotic & 31 \\
Non-cirrhotic & 37 \\
$\quad$ Information not available & 32 \\
Genotype & \\
Genotype 1 & 59 \\
Genotype 2 & 4 \\
Genotype 3 & 1 \\
Genotype 4 & 2 \\
Genotype 5 & 1 \\
Information not available & 33 \\
Comorbidity & \\
Coinfection with HIV & 27 \\
Coinfection with HBV & 2 \\
\hline
\end{tabular}

coinfected with HIV and 2\% were coinfected with HBV. Table III presents data regarding treatment with PEG-IFN and RBV: 143 patients (76\%) received PEG-IFN alfa-2a (180 mcg) and 45 patients (24\%) received PEGIFN alfa-2b (1.5 mg/kg). Thirty-four (18\%) patients were 
receiving retreatment and of these, $94 \%$ had been previously treated with IFN associated with RBV.

Regarding access, $46 \%$ of patients had prescriptions from private consultations and most received medication through the CEAF of the Public Health Service (74\%), while $26 \%$ received medication following lawsuits filed against the State.

TABLE III - Frequency of variables related to access and medical treatment of patients receiving treatment for chronic hepatitis $\mathrm{C}$ at the PAMMI/HNR between 2005 and 2008

\begin{tabular}{lc}
\hline Variables & $\%(\mathrm{~N}=188)$ \\
\hline Medication & \\
$\quad$ Peginterferon alfa 2a 180 mcg & 75 \\
$\quad$ Peginterferon alfa 2b $120 \mathrm{mcg}$ & 25 \\
Prescription precedence & \\
$\quad$ Not Public Health Service & 46 \\
$\quad$ Public Health Service & 39 \\
$\quad$ Information not available & 15 \\
Access to drugs & \\
$\quad$ CEAF & 74 \\
$\quad$ Lawsuit & 26 \\
Retreatment & \\
$\quad$ Yes & 18 \\
$\quad$ No & 73 \\
Information not available & 9 \\
First treatment type (N=33) & \\
Interferon alfa + ribavirin & 94 \\
Peginterferon alfa 2b 180 mcg + ribavirin & 3 \\
Others & 3 \\
\hline
\end{tabular}

Figure 1 presents a flow chart showing the number of patients who received treatment with PEG-IFN in association with RBV $(n=188)$, the number of patients who concluded complete treatment $(n=176)$, the number of medical records located $(n=129)$, the number of patients with records of their exams ( $n=94)$, the number of patients presenting a response at the end of treatment $(n=68)$ and the number of patients achieving SVR $(n=24)$.

Among the 129 patients located in the study, seven died. When a patient dies during the treatment, their death is invariably associated with the treatment; however, the causes of death were not investigated, thus is not possible to affirm whether their deaths were related to hepatitis $\mathrm{C}$. Of the 122 records located, 94 were submitted to at least one of the qualitative HCV RNA exams at the end of treatment and/or SVR.

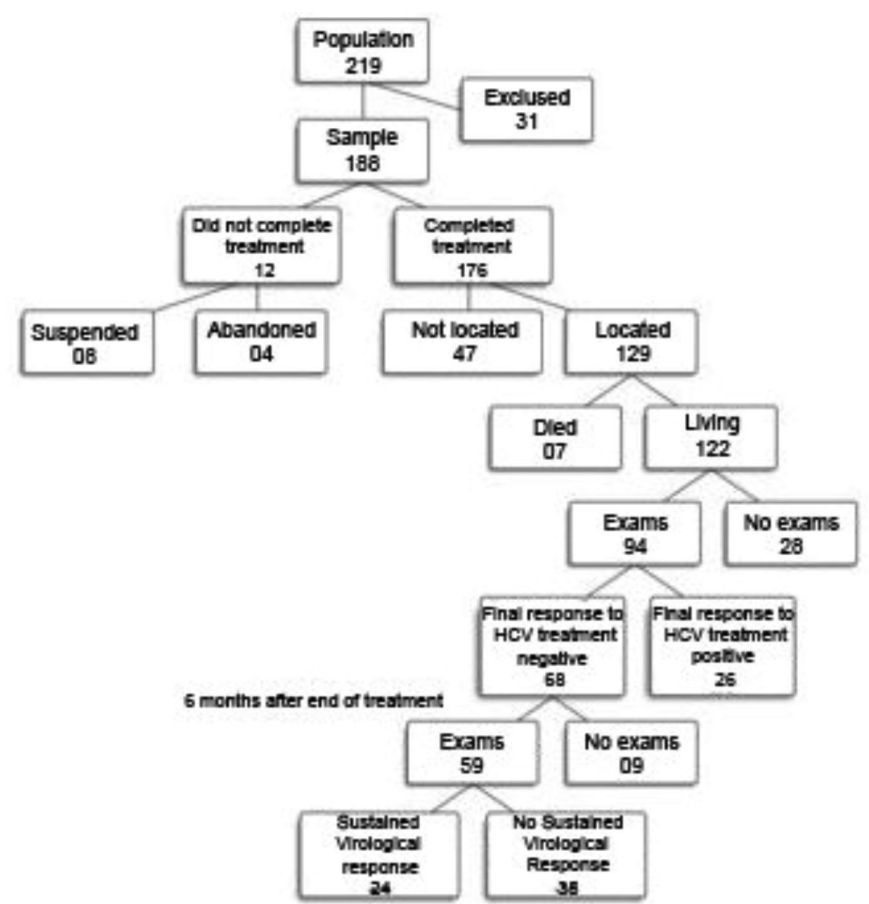

FIGURE 1 - Flow chart with the number of patients who started, completed and who obtained a response at the end and the SRV of patients receiving treatment for chronic hepatitis $\mathrm{C}$ at the PAMMI/HNR between 2005 and 2008.

The SVR rate calculated by the theory of probability was $26 \%$. Considering the likelihood of all those not located and those without records of exams achieving SVR, the real rate could be $57.4 \%$; on the other hand, if all these patients did not achieve SVR, the rate would have been $12.8 \%$. The latter is the same value obtained by calculating the intention to treat $(24 / 188)$.

Considering two groups of patients, those naive or on retreatment, the SVR rates are $41.9 \%$ and $40.0 \%$ respectively, without significant statistics.

Associations between SVR and the variables sex, age, genotype and cirrhosis were determined and only sex and age were significantly associated with SVR (Table IV).

\section{DISCUSSION}

The demographic characteristics of patients treated at the PAMMI/HNR are in agreement with similar Brazilian studies evaluating the efficacy of PEG-IFN (Almeida et al., 2009; Brandão et al., 2006; Mourão et al., 2008; Silva et al., 2007). As in other studies, male predominance can be explained by greater exposure of men to disorders that affect health throughout their lives and their resistance to seeking preventive medical care (Braz, 2005). In this group of patients, the greater percentage of patients aged over 40 years old is probably associated with the higher 
TABLE IV - Test of association between SVR and predictor variables (sex, age, genotype and cirrhosis) of patients receiving treatment for chronic hepatitis $\mathrm{C}$ at the PAMMI/HNR between 2005 and 2008

\begin{tabular}{lccc}
\hline Variables & SRV $(\%)$ & no SRV $(\%)$ & $P$ \\
\hline Sex & & & \\
$\quad$ Male & 58.3 & 85.7 & 0.017 \\
$\quad$ Female & 41.7 & 14.3 & \\
Age & & & \\
$\quad \geq 40$ years old & 75.0 & 94.3 & 0.003 \\
$\quad<40$ years old & 25.0 & 5.7 & \\
Genotype & & & \\
$\quad$ 1 & 75.0 & 80.0 & 0.648 \\
$\quad$ Not 1 & 25.0 & 20.0 & \\
Cirrhosis & & & \\
$\quad$ Present & 25.0 & 31.4 & 0.275 \\
$\quad$ Absent & 75.0 & 45.7 & \\
\hline
\end{tabular}

risk of exposure to the HCV over time (Quaglio et al., 2003).

Blood transfusion was the route of $\mathrm{HCV}$ acquisition reported by most patients in the study; however, hepatitis $\mathrm{C}$ notification data from the Department of Epidemiological Surveillance for the period 2002 to 2004 indicate injectable drug use as the main route of acquiring the disease (Goncalves et al., 2008). It should be emphasized that the exposure data collected in this study originates from interviews with patients conducted at the onset of treatment and recorded in the medical records. Self-reporting is not the most reliable data source and may not reveal the true risk factor of exposure, thus justifying the difference between these results. Moreover, blood transfusion was the main transmission route before 1993 when $\mathrm{HCV}$ testing was not available.

Although no correlation between SVR and cirrhosis was determined in this sample, the significant percentage of patients with cirrhosis $(30 \%)$ could be a complicating factor in achieving SVR, since the degree of fibrosis and inflammatory activity is indicative of the prognosis of patients with chronic $\mathrm{HCV}$ infection (Fried, Hadziyannis, 2004; NICE, 2006; NIH, 2002).

Brazilian and foreign studies that have investigated HCV-HIV coinfection report SVR rates between 25 and 30\% (Alter, 2006; Segurado et al., 2004; Tovo et al., 2007). A percentage of $27 \%$ of patients presenting HCVHIV coinfection follows the trend of these studies and the presence of this factor is considered poor prognosis for achieving SVR.
A number of studies indicate high prevalence of genotype 1 in Brazil (Diament, 2007; Perrone et al., 2008). Since the sample consisted of patients who used PEG-IFN, a higher percentage of patients with genotype 1 was expected. HCV genotype is an important parameter in the indication of treatment, given that genotype 1 presents lower rates of SVR compared with other genotypes, which is why patients with genotype 1 are treated for 48 weeks, while patients with other genotypes are treated for 24 weeks (Ferreira, 2007; Fried, Hadziyannis, 2004; Shepherd et al., 2007).

Other prognostic factors considered unfavorable for achieving SVR include being male, greater age, longer duration of infection, alcohol abuse and immunosuppression (Fried, Hadziyannis, 2004; NICE, 2006; NIH, 2002; Shepherd et al., 2007).

Analysis of the data verified that most patients were treated with PEG-IFN 2a, which can be partially explained by competition and sales teams in the pharmaceutical industry. Recently, a systematic review of clinical trials compared the two forms of commercially available PEG-IFN. In this review, PEG-IFN 2a showed a significant increase in the number of patients who presented SVR compared to PEG-IFN 2b (47\% vs. 41\%, RR 1.11, 95\%CI 1:04-1:19, $\mathrm{p}=0.004)$. No significant differences in the presentation of adverse effects were verified (Awad et al., 2010).

Observation verified that most patients seek private care or healthcare plans for diagnosis and treatment prescription. This is probably because tests like genotyping, biopsy, qualitative and quantitative HCV RNA, often involve queues when accessed through the Public Health Service. In our opinion, this creates a bottleneck of access, where patients who subscribe to or can afford private healthcare plans have greater access to medications for the treatment of hepatitis C.

Approximately one third of the group of patients evaluated obtained their medications by means of lawsuits against the State of Santa Catarina, the majority in disagreement with the Brazilian clinical protocol, mainly for retreatment and for patients presenting coinfection with HIV and genotypes other than 1. Such treatments were only permitted from September 2007 onward, following the publication of the new Brazilian clinical protocol for the treatment of chronic hepatitis C (Brasil, 2007).

Only a few well-conducted randomized clinical trials have evaluated HCV retreatment using PEG-IFN. Those that have report SVR rates between 8 and $26 \%$ for patients who were previously treated with IFN (Jensen, Marcellin, 2005; Taliani, Biliotti, 2007). Only two of the 33 patients receiving retreatment at the PAMMI/HNR achieved SVR, which corresponds to $6.1 \%$, lower than the literature data. 
Of the 188 patients who received treatment, only 12 did not conclude, indicating a high percentage of conclusions compare to others studied conducted in Brazil (Almeida et al., 2009; Narciso-Schiavon et al., 2010). Certain characteristics verified during the follow-up of these patients suggest the reasons for this rate of conclusion, such as the safety of procedures performed in the service, weekly follow-up by a qualified team to manage the side effects and complications of treatment, and the integration and adaptation of patients attending the service for about a year.

Only 59 of the 129 patients located were submitted to the SVR exam, revealing a lower percentage than expected. In some cases, these patients reported no interest in knowing the treatment outcome.

Given this low percentage of results concerning treatment effectiveness, certain assumptions can be made: 1) the results of these exams are probably being retained in physicians' offices; 2) patients loose the medical reports or may not want to remember the feelings that they were exposed to during treatment; 3) clinical follow-up is often ineffective after treatment.

When comparing the present results $(12.8 \%$ for intention to treat) with those of international clinical trials, the SVR rate obtained is much lower than that reported in the literature, with several studies showing results for treatment efficacy close to 50\% (Awad et al., 2010; Fried et al., 2002; Fried, Hadziyannis, 2004; Manns et al., 2001; et al., 2004; Mchutchison, Sulkowski, 2008; Poynard et al., 1996), thus reflecting problems in routine patient care in Brazilian services. In clinical trials, patients are selected by strict inclusion criteria and are attended in a standardized and differentiated manner, which in practice is not possible, because the services are often undersized in terms of infrastructure and human resources in relation to the existing demand.

Patients in the group analyzed presented clinical characteristics predictive of a lower rate of SVR (genotype 1, male, aged over 40 years old and the presence of cirrhosis), although only age and sex were statistically significant.

Higher SVR rates were observed in patients younger than 40 years of age, as demonstrated in another study (Lindsay et al., 2001). The association between sex and SVR was significant, in disagreement with another study conducted in Brazil (Narciso-Schiavon et al., 2010). In this study, the presence of cirrhosis was not significantly associated with SVR, even though the currently accepted hypothesis is that the smaller the degree of fibrosis, the higher the SVR rates for treatment (Poynard et al., 2000).

When evaluating the findings of this study, certain observations should be considered. The study involved patients from different municipalities in the greater Florianópolis area and the patients were clinically followed in both public health services and private clinics, thus, possible differences between clinical follow-up, performance of exams and consultation procedures may exist. The biopsies and laboratory exams were performed in several laboratories, possibly using different methodologies. No analysis regarding the standardization of ribavirin given to patients during treatment was performed and at any given moment of treatment, patients may have received different brands, because State legislation requires bidding processes for all acquisitions and the health service where the patients were attended made no record of the brand or manufacturer.

Moreover, the study revealed a significant loss of data regarding the outcomes evaluated, since almost half of the patients had no results verifying SVR status. We attempted to correct for this loss of data using probability calculations, thus extending the proportions for patients not located and those who no longer had or were not submitted to the required exams.

This absence of data indicates the need for adequate health services for full implementation of assistance activities. Hepatitis $\mathrm{C}$ is a disease requiring notification and treatment outcome must form part of the surveillance activities of the National Health Program for the Prevention and Control of Viral Hepatitis.

Moreover, the lack of response to treatment or the failure to achieve SVR constitutes yet another problem for the Brazilian National Health Service because the treatment is being provided could be ineffective or not achieving the expected response rates. Patients who did not respond to treatment remain a potential source of new infections, remain exposed to the risk of aggravation of the disease and could evolve to liver failure.

The participation of pharmacists in collecting and analyzing the data permitted a clearer understanding of the reality of proposing pharmacotherapeutic follow-up.

\section{CONCLUSIONS}

In the group studied, the rate of discontinued treatment was low compared to other studies. However, both the SVR rate calculated by the theory of probability of $26 \%$ and by intention to treat of $12.8 \%$ are considered low values for the outcome of treatment of hepatitis $\mathrm{C}$ with peginterferon alfa combined with ribavirin. This result may be related to the demographic and clinical characteristics of the patients studied, considered a "poor prognosis group". 


\section{CONFLICT OF INTEREST}

The authors declare that there are no conflicts of interest.

\section{FINANCIAL SUPPORT}

Edict for research projects and technological developments of priority for the National Unified Health System (SUS), MS/CNPq/FAPESC/SES - 008/2006.

Consultancy for the elaboration of research, evaluation and systematization of information to support the Pharmacy Therapeutic Commission and the development of the Therapeutic Protocol of the DIAF/SES-SC.

\section{REFERENCES}

ALMEIDA, P.R.L.; MATTOS, A.A.; AMARAL, K.M; FELTRIN, P.Z.; TOVO, C.V.; PICON, P.D. Treatment of hepatitis $\mathrm{C}$ with peginterferon and ribavirin in a Public Health Program. Hepato-gastroenterol., v.56, p.223-226, 2009.

ALTER, M.J. Epidemiology of hepatitis C in the West. Semin. Liver. Dis., v.15, p.5-14, 1995.

ALTER, M.J. Epidemiology of viral hepatitis and HIV coinfection. J. Hepatol., v.44, p.6-9, 2006.

ANDRADE, T.U.; BURINI, D.M.; MELLO, M.O.; BERSÁCULA, N.S.; SALIBA, R.A.D.; BRAVIM, F.T.; BISSOLI, N.S. Evaluation of the satisfaction level of patients attended by a Pharmaceutical Care Program in a Private Communitarian Pharmacy in Vitória (ES, Brazil). Braz. J. Pharm. Sci., v.45, p.349-355, 2009.

AWAD, T.; THORLUND, K.; HAUSER, G.; STIMAC, D.; MABROUK, M.; GLUUD, C. Peginterferon alpha-2a is associated with higher sustained virological response than peginterferon alfa-2b in chronic hepatitis $C$ : Systematic review of randomized trials. Hepatology, v.51, n.4, p.11761184,2010

BLATT, C.R.; ROSA, J.A.; SANDER, G.; FARIAS, M.R. Tratamento da hepatite $\mathrm{C}$ e qualidade de vida. Rev. Bras. Farm., v.90, p.19-26, 2009.
BRANDÃO, C.; BARONE, A.; CARRILHO, A.; SILVA, M.; PATELLI, M.; CARAMORI, C.; FOCACCIA, R.; PEREIRA, L.; PEDROSO, M.; TATSCH, F.; PESSOA, $\mathrm{M}$. The results of a randomized trial looking at 24 weeks VS 48 weeks of treatment with peginterferon a-2a $(40 \mathrm{kDa})$ and ribavirin combination therapy in patients with chronic hepatitis C genotype 1. J. Viral Hepat., v.13, p.552-559, 2006.

BRASIL. Ministério da Saúde. Secretaria de Vigilância em Saúde. SAS/MS Portaria nº. 34, de 23 set. 2007. Dispõe sobre Protocolo Clínico e Diretrizes Terapêuticas para Hepatite Viral C. Brasília, DF: Ministério da Saúde, 2007. 28 set. p.60.

BRAZ, M.A. A construção da subjetividade masculina e seu impacto sobre a saúde do homem: reflexão bioética sobre a saúde do homem: reflexão bioética sobre saúde distributiva. Ciênc. Saúde Colet., v.10, p.97-104, 2005.

CHIEFFI, A.L.; BARATA, R.B. Judicialização da política pública de assistência farmacêutica e eqüidade. Cad. Saúde Pública, v.25, n.8, p.1839-1849, 2005.

CORRER, C.J.; PONTAROLO, R.; SOUZA, R.A.P.; VENSON, R.; MELCHIORS, A.C.; WIENS, A. Effect of a Pharmaceutical Care Program on quality of life and satisfaction with pharmacy services in patients with type 2 diabetes mellitus. Braz. J. Pharm. Sci., v.45, p.809-817, 2009.

DIAMENT, D. Epidemiological aspects of hepatitis $\mathrm{C}$ in Brazil. Braz. J. Infect. Dis., v.11, n.5, suppl. 1, p.6-7, 2007.

FERREIRA, M.S. Treatment of chronic hepatitis $\mathrm{C}$ in treatmentnaïve patients. Braz. J. Infect. Dis., v.11, n.5, suppl.1, p.45-49, 2007.

FRIED, M.W.; HADZIYANNIS, S.J. Treatment of chronic hepatitis $C$ infection with peginterferons plus ribavirin. Semin. Liver Dis., v.24, suppl.2, p.47-54, 2004.

FRIED, M.W.; SHIFFMAN, M.L.; REDDY, K.R.; SMITH, C.; MARINOS, G.; GONÇALES, F.L.J.; HAUSSINGER, D.; DIAGO, M.; CAROSI, G.; DHUMEAUX, D.; CRAXI, A.; LIN, A.; HOFFMAN, J.; YU, J. Peginterferon alfa-2a plus ribavirin for chronic hepatitis $\mathrm{C}$ virus infection. N. Engl. J. Med., v.347, p.975-982, 2002. 
GONÇALVES, S.; DAMINELLI, E.N.; SPADA, C.; HAAS, P. Panorama da hepatite $\mathrm{C}$ no estado de Santa Catarina e na cidade de Florianópolis. Rev. Bras. Anal. Clin., v.40, p.57-60, 2008.

HADZIYANNIS, S.J.; SETTE, H.J.; MORGAN, T.R.; BALAN, V.; DIAGO, M.; MARCELLIN, P.; RAMADORI, G.; BODENHEIMER JR., H.; BERNSTEIN, D.; RIZZETTO, M.; ZEUZEM, S.; POCKROS, P.J. Peginterferon-alpha2a and ribavirin combination therapy in chronic hepatitis $\mathrm{C}$ : a randomized study of treatment duration and ribavirin dose. Ann. Intern. Med., v.140, p.346-355, 2004.

JENSEN, D.M.; MARCELLIN, P. Rationale and design of the REPEAT study: a phase III, randomized, clinical trial of peginterferon alfa-2a (40 kDa) plus ribavirin in nonresponders to peginterferon alfa- $2 \mathrm{~b}(12 \mathrm{kDa})$ plus ribavirin. Eur. J. Gastroenterol. Hepatol., v.17, p.899-904, 2005.

LINDSAY, Y.K.L.; TREPO, C.; HEINTGES, T.; SHIFFMAN, M.L.; GORDON, S.C.; HOEFS, J.C.; SCHIFF, E.R.; GOODMAN, Z.D.; LAUGHLIN, M.; YAO, R.; ALBRECHT, K.K. A randomized, double-blind trial comparing pegylated interferon alfa- $2 b$ to interferon alfa$2 \mathrm{~b}$ as initial treatment for chronic hepatitis C. Hepatology, v.34, p.395-403, 2001.

MANNS, M.P.; MCHUTCHISON, J.G.; GORDON, S.C.; RUSTGI, V.K.; SHIFFMAN, M.; REINDOLLAR, R.; GOODMAN, Z.D.; KOURY, K.; LING, M.H.; ALBRECHT, J.K. Peginterferon alfa-2b plus ribavirin compared with interferon alfa-2b plus ribavirin for initial treatment of chronic hepatitis C: a randomised trial. Lancet, v.358, p.958-65, 2001.

MCHUTCHISON, J.; SULKOWSKI, M. Scientific rationale and study design of the individualized dosing efficacy vs flat dosing to assess optimal pegylated interferon therapy (IDEAL) trial: determining optimal dosing in patients with genotype 1 chronic hepatitis C. J. Viral Hepatitis, v.15, p.475-481, 2008.

MOURÃO, L.C.S.; ALVES, L.D.S.; LOPES, J.V.S.J.; NUNES, L.C.C.; MEDEIROS, M.G.F. Caracterização da hepatite C em pacientes assistidos pelo Programa de Medicamentos de Dispensação em caráter excepcional. Rev. Bras. Farm., v.89, p.226-229, 2008.

MULHALL, B.P.; YOUNOSSI, Z. Impact of adherence on the outcome of antiviral therapy for chronic hepatitis C. J. Clin. Gastroenterol., v.8, n.39, suppl.1, p.23-27, 2008.
NARCISO-SCHIAVON, J.L.; SCHIAVON, L.L.; CARVALHOFILHO, R.J.; SAMPAIO, J.P.; BATAH, P.N.E.; BARBOSA, D.V.; FERRAZ, M.L.G; SILVA, A.E.B. Gender influence on treatment of chronic hepatitis C genotype 1. Rev. Soc. Bras. Med. Trop., v.43, n.3, p.217-223, 2010.

NATIONAL INSTITUTE FOR HEALTH AND CLINICAL EXCELLENCE. PegIFN and ribavirin for the treatment of mild chronic hepatitis C. London, 2006. 31 p. (NICE technology appraisal guidance, 106).

NIH. Consensus Developmente Program. Management of Hepatitis C: 2002. Available at: <http://consensus.nih.go v/2002/2002HepatitisC2002116html.htm>. Acessed on: $11^{\text {th }}$ jun. 2012 .

PERRONE, C.; CASTILLO, D.M.; PEREIRA, G.L.; CARVALHO, N.O.; JANUARIO, J.N.; TEIXEIRA, R. High prevalence of genotype 1 in individuals with hepatitis C in Belo Horizonte, MG. Rev. Soc. Bras. Med. Trop., v.41, p.238-242, 2008.

POYNARD, T.; LEROY, V.; COHARD, M.; THEVENOT, T.; MATHURIN, P.; OPOLON, P. Meta-analysis of interferon randomized trials in the treatment of viral hepatitis $C$ : effects of dose and duration. Hepatology, v.24, p.778-896, 1996.

POYNARD, T.; MCHUTCHISON, J.; GOODMAN, Z.; LING, M.H.; ALBRECHT, J. Is an "a la carte" combination interferon alfa-2b plus ribavirin regimen possible for the first line treatment in patients with chronic hepatitis $\mathrm{C}$ ? Hepatology, v.31, p.211-218, 2000.

QUAGLIO, G.; LUGOBONI, F.; PAJUSCO, B.; SARTI, M.; TALAMINI, G.; LECHI, A. et al. . Factors associated with hepatitis $\mathrm{C}$ virus infection in injection and noninjection drug users in Italy. Clin. Infect. Dis., v.37, p.33-40, 2003.

SEGURADO, A.C.; BRAGA, P.; ETZEL, A.; CARDOSO, M.R. Hepatitis $C$ virus coinfection in a cohort of HIVinfected individuals from Santos, Brazil: seroprevalence and associated factors. AIDS Patient Care, v.18, p.135-143, 2004.

SHEPARD, J.; FINELLI, A. Global epidemiology of hepatitis C virus infection. Lancet Infect. Dis., v.5, p.558-567, 2005. 
SHEPHERD, J.; JONES, J.; HARTWELL, D.; DAVIDSON, P.; PRICE, A.; WAUGH, N. IFN (pegylated and nonpegylated) and ribavirin for the treatment of mild chronic hepatitis C: a systematic review and economic evaluation. Health Technol. Assess., v.11, p.1-205, 2007.

SILVA, G.F.; POLONIO, R.J.; PARDINI, M.I.M.C.; CORVINO, S.M.; HENRIQUES, R.M.S.; PERES, M.N.; SILVEIRA, L.V.A.; COELHO, K.I.R. Using Pegylated IFN-2b and ribavirin to treat chronic hepatitis patient infected with hepatitis $\mathrm{C}$ vírus genotype 1: are nonresponders and relapsers different populations? Braz. J. Infect. Dis., v.11, p.554-560, 2007.

SPIEGEL, B.M.; YOUNOSSI, Z.M.; HAYS, R.D.; REVICKI, D.; ROBBINS, S.; KANWAL, F. Impact of hepatitis C on health related quality of life: a systematic review and quantitative assessment. Hepatology, v.41, p.790-800, 2005.
TALIANI, G.; BILIOTTI, E. Retreatment of chronic hepatitis $\mathrm{C}$ patients non responder to a previous antiviral treatment. Recenti Prog. Med., v.98, p.219-224, 2007.

TOVO, C.V.; MATTOS, A.A.; SOUZA, A.R.; RIGO, J.F.O.; ALMEIDA, P.R.L.; GALPERIM, B.; SANTOS, B.R. Impact of human immunodeficiency virus infection in patients infected with the hepatitis C virus. Liver Int., v.27, p.40-46, 2007.

VIEIRA, F.S. Ações judiciais e direito à saúde: reflexão sobre a observância aos princípios do SUS. Rev. Saúde Púb., v.42, p.365-369, 2008.

WETTERMARK, B.; PERSSON, M.E; WILKING, N.; KALIN, M.; KORKMAZ, S.; HJEMDAHL, P.; GODMAN, B.; PETZOLD, M.; GUSTAFSSON, L.L. Forecasting drug utilization and expenditure in a metropolitan health region. BMC Health Serv. Res., v.10, p.1-14, 2010.

Received for publication on $19^{\text {th }}$ April 2011 Accepted for publication on $05^{\text {th }}$ April 2012 
